\title{
On China's Excellent Traditional Culture and Innovation of Ideological and Political Education in Colleges and Universities
}

\author{
Yingfeng $\mathrm{Xu}$ \\ School of Marxism \\ Quanzhou Normal University \\ Quanzhou, China \\ xuyingfeng118@126.com
}

\author{
Jingxian $\mathrm{Xu}^{*}$ \\ TSL School of Business and Information Technology \\ Quanzhou Normal University \\ Quanzhou, China \\ yjsxjx@126.com
}

\begin{abstract}
At present, the ideological and moral education of college students is in a chaotic state, and the Chinese traditional culture has a moral connotation. Therefore, it is of great significance to innovate the ideological and political education in Colleges and universities with traditional culture. The purpose of this study is to find out some similarities between traditional culture and ideological and political education in Colleges and universities, and formulate innovative strategies for ideological and political education in accordance with these common points. By referring to a large number of documents, this project not only generalizes the common points of traditional culture and ideological and political education, but also concludes the common points between traditional culture and Marx doctrine. Finally, this project demonstrates that it is feasible to innovate the ideological and political education in Colleges and universities with traditional culture. Our research shows that colleges and universities can innovate the ideological and political education by taking some corresponding strategies. These strategies are: to integrate the essence of traditional culture, to create new methods of Ideological and political education, and to strengthen the construction of traditional culture education in Colleges and universities. This study provides a new idea for ideological and political education in Colleges and universities throughout the country.
\end{abstract}

Keywords-Excellent traditional culture; Ideological and Political Education; Innovate; Marx doctrine

\section{INTRODUCTION}

In the era of globalization and multi-cultural background, ideological and political education in Colleges and universities is confronted with cultural problems. How does this puzzle seek unity among cultures? How to actively guide and educate contemporary college students? How can ideological and political education play a role in improving the effectiveness of Ideological and political education? These are the problems that schools must face up to and solve.

\section{UNDER THE BACKGROUND OF GLOBALIZATION, THE IDEOLOGICAL AND POLITICAL EDUCATION IN COLLEGES AND UNIVERSITIES IS FACED WITH NEW SITUATIONS AND NEW PROBLEMS}

\section{A. In the age of globalization, multi culture faces challenges}

With the acceleration of globalization, economic transformation, political reform and social development, culture needs to play a guiding and innovative function. Because of the good morals and thrifty habits of the Chinese nation, China can successfully use globalization to develop the national economy. But in the process of globalization in the western countries not only spread the advanced science and technology, but also the spread of western culture, the western ideology penetration into Chinese social culture; globalization promotes common ethnic communication and mutual dependence, promote multicultural communication. However, the differences in cultural values have brought about many obstacles and contradictions to the economic, political, ideological and cultural exchanges among different countries. These contradictions are manifested in values, religions and even military affairs. Therefore, in the process of globalization, the cultural value of the nation is difficult to grasp its deepseated reasons from the complex changes. It is also difficult to reasonably explain the confusions and contradictions in contemporary human spiritual life.

Multiculturalism has brought new problems to social ethics and the ideological and moral development of young people. The task of Ideological and political education in Colleges and universities has two aspects. On the one hand, colleges and universities should actively create a healthy and benign multicultural environment, so that globalization can be promoted from spontaneous to conscious. On the other hand, colleges and universities should constantly innovate educational methods and means to inspire and guide individual cultural choices, so as to enable students to adapt to the challenges posed by multiculturalism in a globalized environment. Universities should give full play to the inherent advantages of traditional culture, and provide theoretical support for the development from conflict to integration and coordination. 
B. In the process of market economy development, new moral problems and moral perplexity emerge

In the market economy, the supremacy of interest causes people to disregard morality in pursuit of profit. To a certain extent, the neglect of humanistic care leads to many abnormal phenomena in society, such as money worship, hedonism, lack of confidence, fraud and so on. People's beliefs begin to be lost, and some become mentally anxious and even degenerate. Some people live in luxury, so there is the phenomenon of greed and selfish, and even cultural crisis of faith.

In the market economy has become the main economic situation, ideological and political education should innovate education concept, to absorb the positive factors China excellent traditional culture, and these positive factors into the socialist market economic system. The ideological and political education in Colleges and universities should integrate the interests principle, the principle of autonomy and the competition principle of the modern market economy into the lofty ideal of life and the lofty pursuit of life. In this way, we can cultivate the talents needed to adapt to the development of China's socialist market economy. Such talent is a material and spiritual balanced development of people, is a healthy talent. Therefore, the ideological and political education in Colleges and universities should not only realize the task of the current economic development, but also achieve the task of improving the moral.

\section{The opportunities and challenges brought about by the development of the internet}

The development of the Internet and the progress of science and technology have not only opened up a huge space for cultural development and communication, but also caused people to lose their private space and spiritual home. It not only causes the crisis of credibility, but also makes people become more and more indifferent, and even humane care is gradually disappearing. In the Internet era, there are conflicts between different cultures, and other cultural values have seriously eroded our social values. Other cultural ideas weaken our national cohesion and centripetal force, and it also weakens people's sense of duty, collective concept, national concept and sense of social responsibility. And individualism, money worship and hedonism are also growing. While the material level is improving, the university students' thoughts are empty, decadent and perplexed. Many college students lack the social responsibility and the basic moral accomplishment of the contemporary college students. Therefore, ideological and political education in Colleges and universities should shoulder the task of improving the ideological and moral standards of College students. The task of Ideological Education in Colleges and universities is to let students learn to respect other cultures in a rational way, to look for cultural commonalities, and to use critical thinking to discriminate between various cultural patterns and cultural values. In this way, we can improve the cultural quality of college students, cultivate the healthy and perfect personality of college students, and promote the allround development of College students.

\section{THE CONJUNCTION OF CHINA'S EXCELLENT TRADITIONAL CULTURE AND IDEOLOGICAL AND POLITICAL EDUCATION IN COLLEGES AND UNIVERSITIES}

In the face of a series of impacts and challenges brought about by globalization, informatization and social transformation, the ideological and political education in Colleges and universities should change with the change of multi culture. This change should be transformed from strengthening a single value concept into a pluralistic concept of value, changing from a traditional standard personality to a diverse personality, from closed training to open thinking.

In 2015, the Ministry of Education issued an innovative plan for the construction of Ideological and political theory courses in Colleges and universities. It pointed out that the ideological and political education in Colleges and universities should carry out the party's educational policy in full. Its basic task is to train qualified builders of socialism, as well as to build codes of ethics and train qualified personnel. The ideological and political theory course is the core curriculum of Ideological and political education, the curriculum not only for students to carry out the education of socialist core values, but also help students to establish a correct world outlook and outlook on life values. Ideological and political theory course should continue to develop and innovate the ideological and political theory course system to meet the requirements of the new era. In December 2016, 7 - 8, the national ideological and political work held a meeting, $\mathrm{Xi}$ Jinping stressed that ideological and political work should run through the process of education and teaching, ideological and political work should start a new situation in the cause. The innovation of Ideological and political education in Colleges and universities is a complex systematic project. These innovations include educational ideas, educational methods, educational means, educational contents, curriculum systems and so on. The innovation of the content of education is the most important part, not only to deal with the relationship between contemporary culture and traditional culture, but also to deal with the relationship between ethnic culture and foreign culture. Although culture is constantly changing, in fact, no one nation can abandon its cultural traditions and start again. Throwing away the foundation of traditional culture and seeking novelty, such consequences will inevitably lead to tragedy [1]. Ideological and political education innovation has many advantages, it can fully tap the existing traditional spiritual resources, update the value system, and promote the formation of contemporary culture.

Therefore, in order to develop and innovate the ideological and political education in Colleges and universities and realize the modernization of education, we must not make a complete break with our traditional culture. And must be rooted in their own culture, learn from their excellent traditional culture. At the same time, it can promote their own cultural development, and also can promote the self-renewal of traditional culture. Innovative ideological and political education in Colleges and universities must be rooted in China's excellent traditional culture. Because China's outstanding traditional culture embodies the spirit of the Chinese nation's self-improvement, it is the deep foundation for the development of advanced socialist culture. It provides the Chinese people with the 
principles of life, the principles and norms of life, as well as the basic views of the universe, nature, society and human destiny. Chinese traditional culture not only expresses strong moralism and positive social concern, but also displays humanitarianism and rational attitude. It emphasizes naturalism in philosophy and the universal concept of harmony between man and nature. China's excellent traditional culture guides the development of our country's moral construction and is the inner embodiment of the socialist core values. Excellent traditional culture is the precious treasure of the Chinese nation, and also a powerful spiritual force to realize the rejuvenation of the Chinese nation. Strengthening the ideological and political education in Colleges and universities and integrating the Chinese excellent traditional culture into the ideological and political education of college students can better improve the level of Ideological and moral cultivation of college students and cultivate a sound personality.

The ideological and political education of college students should be guided by the theory of Marx, absorb the essence of the Chinese nation's excellent traditional culture, and integrate the traditional culture into the thought of Marx. Traditional culture can become a system open to the future, and maintain vitality in the continuity of history. The innovation of Ideological and political education of college students can realize the organic combination of mainstream ideology and traditional culture, and realize the organic combination of Marx and traditional culture.

\section{INNOVATING IDEOLOGICAL AND POLITICAL EDUCATION SHOULD REALIZE THE FUSION OF FINE TRADITIONAL CULTURE AND MARX DOCTRINE}

Colleges and universities are the main places for propaganda of Marx theory, strengthen the main task of Ideological and political education of college students is to improve the theoretical level of the Marx doctrine, improve the theoretical level of the scientific world view, improve the theoretical level of methodology, and apply them to analyze and solve problems. The innovation of Ideological and political education must be based on the theory of Marx. Combining mainstream ideology with national culture, we should not only interpret Marx doctrine with national culture, but also transform and promote national culture with Marx doctrine. In the course of the spread and development of Marx doctrine, we should integrate national culture and Marx doctrine, and constantly improve the national cultural quality and enhance the cultural influence of the country.

Mr. Zhang Dainian once pointed out: "the combination of Marx doctrine and Chinese excellent cultural tradition should be the leading direction of Chinese cultural development [2]." It improves the ideological and political level and moral cultivation of college students. It is necessary to develop the Marx doctrine in China and realize the modernization of Chinese traditional culture. Moreover, it is necessary to educate college students' rational understanding of traditional culture. Combine the fine traditional culture of China with the doctrine of Marx, so that we can achieve the purpose of Ideological and political education in Colleges and universities.

\section{A. China's excellent traditional culture contains the dialectical thought of Marx}

Chinese traditional culture has profound implications. It contains contradictory opposites and unified thinking, and Marx doctrine also contains this idea. Lao Tzu is a dialectical master of Chinese classical philosophy. Lao Zi's dialectics thought is a very important component of Chinese traditional philosophy. From a theoretical point of view, Lao Tzu's dialectic thought has much in common with today's Marx philosophy. Lao Tzu believes that all things are contradictory combinations, and all things are mutually exclusive and interdependent. In his book the book of morals, he listed nearly one hundred oppositions of two variables. Such as: Yin and Yang, heaven and earth, beauty and ugliness, good and evil, static and moving, and so on. Lao Tzu pointed out that "there is not much difference between good and evil, there is no absolute boundary between good and evil, and they can be transformed with each other". The two sides of the [3] contradiction depend on each other and will transform each other under certain conditions.

\section{B. The truth and goodness in Chinese traditional culture reflect the dialectical relation between truth and value of} Marx doctrine

Chinese traditional culture emphasizes seeking truth and pragmatism. Chinese traditional culture pays much attention to reality and human life. Therefore, seeking truth is the Chinese people's cognitive principles and moral principles, and the spiritual essence of Chinese traditional culture. They stressed that according to the true appearance of things to reveal the nature and laws of things, to the scientific and realistic attitude to understand the world. Lao Tzu believes that everything must follow the laws of nature. Confucianism emphasizes the coordination between people and puts forward the thought of benevolence. If a man wants to be kind, he should have generous heart and respect other people. The spirit of the Chinese nation includes broad benevolence and tolerance, and the coordination of human relations is the essence of good. The moral meaning of kindheartedness is dialectical unity with the truth of Marx doctrine, and it is the unity of scientific spirit and humanistic spirit.

\section{The thought of "people as the basis" in Chinese traditional culture embodies the mass viewpoint in historical materialism}

The historical materialism of Marx's doctrine clearly points out that the masses are the creators of history, and that the masses are the creators of material wealth and spiritual wealth, and that the masses are the decisive force in changing society. Chinese traditional culture contains a lot of people oriented thinking, such as "win the hearts and minds of the people to win the world, the loss of the people, the world lost." In the process of revolution, construction and reform, the Communist Party of China combines the thought of "people as the root" with the thought of Marx. Therefore, the Communist Party of China put forward: "only the people, is the power to create the world [4]." The Chinese Communist Party also compared the feelings between the army and the people to the feelings 
between fish and water, and put forward the purpose of "serving the people wholeheartedly."

\section{CHINESE TRADITIONAL CULTURE AND THE INNOVATION} OF IDEOLOGICAL AND POLITICAL EDUCATION IN UNIVERSITIES

In the new century, the core of our ideological and political education lies in whether we can fully carry forward the Chinese traditional culture of Confucianism, and the traditional Chinese culture into our contemporary ideological and political education system, so that ideological and political education rooted in the Chinese nation's outstanding traditional culture. At the same time, we should take advantage of the favorable factors in the process of world cultural development and establish the policy of Ideological and political education. This policy should not only highlight the spirit of the times, but also reflect the essence of history and culture, and it should also have Chinese characteristics, but also in line with the trend of historical development. This is our country's current ideological and political education innovation work of the basic ideas.

\section{A. Integrating the essence of traditional culture and integrating the essence of traditional culture with ideological and political education}

Chinese traditional culture has moral content, so it plays a more and more important role in Ideological and political education in china. Chinese traditional culture includes traditional ethics, collective concept, patriotism, harmonious thought and self-improvement spirit [5]. These spirit not only can create a positive cultural atmosphere, and can help students to establish a sense of historical responsibility and national mission. All these indicate that Chinese traditional culture has the function of Ideological and moral education. Under the current conditions, the importance of Chinese traditional culture to ideological and moral education is gradually emerging. Chinese traditional culture has become an important source of Ideological and political education innovation in China, and played a great role in the process of upgrading ideological and political education. Therefore, in the process of upgrading China's ideological and political education, we should pay more attention to China traditional culture, promote the ideological and political education upgrading smoothly, so as to realize the ideological and political education and China excellent traditional cultural integration.

\section{B. We should create new ways of Ideological and political education and improve the neglect of traditional culture}

Because of various reasons, our country neglected the education of traditional culture, which led to the neglect of traditional culture, and even some people knew nothing about the traditional culture [6]. To change this situation, we need to carry out the following aspects. First of all, in the primary and secondary school, we should increase some traditional culture courses. Traditional culture should lay a good foundation in the primary and secondary schools. It can start with many subjects, and different disciplines focus on different aspects. Secondly, to improve the teaching methods of students' Ideological and moral courses, and to enhance students' interest in learning. Schools can organize various activities. These activities include lectures on ethical, cultural and cultural practices. Use these activities to improve the students' self-cultivation. Finally, in the ideological and political course of college students to join the content of traditional culture. The key means to develop Chinese traditional culture lies in education, so we should integrate traditional culture into the ideological and political courses in Colleges and universities.

\section{Grasp the characteristics of the transformation of traditional culture, strengthen the construction of traditional culture education in Colleges and Universities}

Chinese traditional culture has a complicated connection with modernization. Therefore, mastering the characteristics of traditional culture plays an important role in Ideological and political education for college students. First, we should strengthen the construction of cultural institutions in Colleges and universities and establish a long-term mechanism for traditional culture and education. Strengthening the system construction can guarantee the smooth progress of the traditional culture education work. Second, colleges and universities should establish a professional team of teachers of traditional culture. Teachers engaged in traditional culture should have relatively high standards. These standards are a strong dedication, sense of responsibility, proficiency in business, study hard, innovative, and understand the specific content of traditional culture. Teachers should convey the spirit of traditional culture to students, so as to achieve the desired teaching objectives.

\section{SUMMARY}

In the current important period of building socialism with Chinese characteristics, it is necessary for college students to study the spirit of the Chinese nation. Combine the fine traditions of the Chinese nation with our socialist modernization drive today. On the basis of development vision and realistic needs, we should strengthen the education of Chinese traditional culture from the long-term strategic objective so as to enrich the current ideological and political education

\section{ACKNOWLEDGMENT}

This work was financially supported by:

The Teaching Reform Foundation Research Funds of School of Marxism, Quanzhou Normal University (2017).

Fujian Province young and middle-aged teacher education research project (Number JAS170399): Xi Jinping's thought of ecological poverty alleviation and its practical significance for the development of Fujian. 


\section{REFERENCES}

[1] Yingyu Yu, Modern interpretation of Chinese ideological tradition, Jiangsu press, 2003 ,pp. 36-36 (In Chinese).

[2] Dainian Zhang, The complete works of Zhang Dainian, Hebei Peoples Publishing House, 1996, pp. 433-433 (In Chinese).

[3] Zhangping Tang, Wang Chaohua, Lao Tzu, Zhong Hua Book Company, 2014, pp. 30-31(In Chinese).
[4] Mao Zedong, Mao's Selected Works, People press, 1991, pp. 1031-1031 (In Chinese).

[5] Xingting Wang, The Traditional Culture of China, China Agricultural University press, 2011, pp.23-24(In Chinese).

[6] DeyangQiao, Shiliang Leng, Hao Ruan, The advantages and disadvantages of Chinese traditional culture in Ideological and political education for College Students, Educational exploration, 2008 ,pp. 109110 (In Chinese). 